\title{
Elicitation of the Prausnitz-Kustner
}

\section{Reaction by Antiidiotypic Antibodies}

\author{
RaIf S. Geha, Division of Allergy, Children's Hospital Medical Center and the \\ Department of Pediatrics, Harvard Medical School, \\ Boston, Massachusetts 02115
}

A B S T R A C T Rabbit antiidiotypic IgG directed against $\left.\operatorname{IgG~} \mathrm{F}(\mathrm{ab})_{2}\right)_{2}$ anti-tetanus toxoid (TT) antibodies ('idiotype") elicited a Prausnitz-Kustner reaction in normal skin sites sensitized $48 \mathrm{~h}$ earlier with the serum of the idiotype donor that contained IgE anti-TT antibodies. The serum moiety that caused the sensitization was heat sensitive $\left(56^{\circ} \mathrm{C}, 1 \mathrm{~h}\right)$, and was specifically removed by passage over immunosorbents containing rabbit antihuman IgE or TT antigen. The data obtained indicate that human IgG and IgE antibodies share idiotypic determinants and raise the possibility that idiotypic interactions may play a role in the regulation of the $\operatorname{IgE}$ antibody response in man.

\section{INTRODUCTION}

Little is known about the relationship between the variable $(\mathrm{V})$ region pool used by the IgE-producing $B$ cells and the $\mathrm{V}$ region gene pools used by $\mathrm{B}$ cells producing antibodies to other isotypes (1). This is a question of considerable interest because the expression of shared idiotypic determinants by $\operatorname{IgE}$ and by $\operatorname{IgG}$ antibodies would suggest that the synthesis of antibodies of both isotypes could be regulated by the same set of idiotypic-antiidiotypic interactions.

In the course of our studies on antiidiotypic (antild) ${ }^{1}$ antisera to human antibodies against tetanus toxoid (TT) in man we came across an allergic subject whose serum contained significant amounts of IgE anti-TT antibody. In the present communication we demonstrate that the IgG anti-TT and IgE anti-TT antibodies

This paper was presented in abstract form at the Meeting of the American Society for Clinical Investigation, San Francisco, CA, April, 1981 .

Dr. Geha is the recipient of Allergic Diseases Academic Award No. K07 AI 00440-01.

Received for publication 19 May 1981 and in revised form 3 November 1981.

${ }^{1}$ Abbreviations used in this paper: antild, antiidiotypic; DT, diphtheria toxoid; P-K reaction, Prausnitz-Kustner reaction; TT, tetanus toxoid. present in the serum of that individual share idiotypic determinants suggesting that the IgE $B$ cell has a $V$ region repertoire similar to that of the IgG $B$ cell.

\section{METHODS}

Human subjects. The subject whose IgG anti-TT antibodies were used to prepare the antild antiserum was a 22 yr-old male with a history of seasonal allergic rhinitis who had positive immediate hypersensitivity prick tests to multiple allergens including grass antigen. This subject gave no history of viral hepatitis and his serum lacked both hepatitis antigen and antibody and was VDRL negative.

The subject in whom the Prausnitz-Kustner $(\mathrm{P}-\mathrm{K})$ reactions were elicited was a 35-yr-old male who gave no personal or family history of allergy, who had negative immediate hypersensitivity prick tests to a standard battery of 36 skin test antigens and whose serum IgE level was $<5 \mathrm{IU} / \mathrm{ml}$. Consent was obtained from both individuals after the purposes of the study were explained to them.

IgE determination and radioallergosorbent tests (RAST). $\mathrm{IgE}$ and allergen-specific $\mathrm{IgE}$ were determined in the serum using the commercially available paper radioimmunosorbent (PRIST) and RAST assays (Pharmacia Fine Chemicals, Piscataway, N. J.). TT was cross-linked to cyanogen bromideactivated cellulose disks (2). Samples that contained $<5 \mathrm{IU}$ $\mathrm{IgE} / \mathrm{ml}(\sim 12 \mathrm{ng} / \mathrm{ml}$, the lower limit of sensitivity of the PRIST assay) and samples that were negative in the RAST assay for TT-specific IgE were analyzed for their content of IgE and IgE anti-TT using a solid-phase radioimmunoassay (3). The sensitivity of this assay for $\operatorname{IgE}$ is $15 \mathrm{pg}$.

IgG determination. IgG was determined by radial immunodiffusion using commercial plates (Calbiochem-Behring Corp., American Hoechst Corp., San Diego, CA). In samples containing $<2 \mathrm{mg} / \mathrm{ml}$ IgG was determined by a fluid-phase radioimmunoassay on $100 \mu$ l of the appropriate dilutions of the sample (14), with a lower limit of sensitivity of $3 \mathrm{ng}$.

Hemagglutination of sheep erythrocytes coated with TT. Hemagglutination titers of serum samples were determined as previously described (5).

Antigens, antisera, and immunosorbents. TT and diphtheria toxoid (DT) antigens were obtained from Massachusetts Biological Laboratories, Boston, MA, and purified by Sephadex G 200 chromatography as previously described (5). Grass antigen was obtained from Hollister-Stier Laboratories, Inc. (Spokane, WA) and dialyzed extensively against phosphate-buffered saline. Rabbit antihuman IgG specific for the heavy chain was purchased from N. L. Cappel Lab- 
oratories, Inc., Cochranville, PA. Rabbit antihuman IgE was raised in rabbits by repeated immunization with purified IgE myeloma P.S. (a kind gift of Dr. Ishizaka, Johns Hopkins University, Baltimore, MD) and was absorbed extensively against kappa and lambda Bence Jones proteins and IgM, IgG, and IgA myeloma proteins cross-linked to Sepharose 4B. Immunosorbents were made to contain $20-25 \mathrm{mg}$ of protein in $1 \mathrm{ml}$ of wet packed Sepharose 4B gel.

Preparation of antiId antiserum. Rabbit antild antiserum directed against human IgG anti-TT antibodies was prepared as described previously (5), except that the IgGenriched fraction of human serum was absorbed extensively against the insolubilized IgG fraction of rabbit antihuman IgE. IgG $F\left(a b^{\prime}\right)_{2}$ fragments obtained by pepsin digestion followed by Sephadex G 150 chromatography were passed over a TT-immunosorbent column pretreated with sodium thiocyanate. The material that did not bind to the column was designated as TT nonreactive IgG $\mathrm{F}\left(\mathrm{ab}^{\prime}\right)_{2}$. The material that was bound to the TT column was eluted with $3 \mathrm{M}$ sodium thiocyanate, designated IgG $F\left(a^{\prime}\right)_{2}$ anti-TT or idiotype and used to immunize a rabbit (5). The IgG fraction of the rabbit antiserum was absorbed extensively against insolubilized TT nonreactive IgG $F\left(a b^{\prime}\right)_{2}$ derived from the idiotype donor to render it idiotype specific.

Radioimmunoassay of antiId IgG. The capacity of rabbit antiId IgG to precipitate ${ }^{125}$ I-labeled IgG $F\left(a^{\prime}\right)_{2}$ anti-TT and to inhibit the binding of ${ }^{125} \mathrm{I}$-labeled-TT and DT antigens to IgG were determined as described previously (5). All radioimmunoassays were done in duplicate.

Serum fractions used for sensitization. Serum obtained from the idiotype donor at the time of the preparation of the $\mathrm{F}\left(\mathrm{ab}^{\prime}\right)_{2}$ was frozen in small aliquots at $-80^{\circ} \mathrm{C}$ until ready for testing or for fractionation. An immunoglobulin (Ig)-enriched fraction was obtained by precipitating $15 \mathrm{ml}$ of serum with an equal volume of saturated ammonium sulfate. The precipitate obtained was dissolved in $15 \mathrm{ml}$ saline and extensively dialyzed. $12 \mathrm{ml}$ of Ig-enriched fraction was absorbed over an anti-IgE Sepharose 4B column. After extensive washing the material bound to the column, was eluted with $12 \mathrm{ml}$ of $3 \mathrm{M}$ sodium thiocyanate and immediately dialyzed against phosphate-buffered saline. Thus the volumes of IgE-depleted fraction and that of the IgE-enriched fraction were equal to the volume of the material applied to the columns. The IgE-enriched serum fraction was absorbed twice against protein containing immunosorbents at a ratio of 2:1 and three times against packed Staphylococcus aureus (Cowan I strain) at a ratio of $4: 1$.

All fractions were sterilized by filtration $(0.45 \mu \mathrm{m}$ filter, Millipore Corp., Bedford, MA) and used immediately or frozen in $0.10 \mathrm{ml}$ aliquots at $-80^{\circ} \mathrm{C}$. Frozen aliquots were thawed once right before use.

Elicitation of the $P-K$ reaction. Skin sites in the flexor area of the recipient's forearm were sensitized by the intradermal injection of $20 \mu \mathrm{l}$ of saline or of $20-\mu \mathrm{l}$ aliquots from various fractions of the donor's serum used at dilutions of $1: 10,1: 50,1: 100,1: 500$, and $1: 1,000$ in normal saline. $48 \mathrm{~h}$ later the sites were challenged by the intradermal injection of $20 \mu \mathrm{l}$ of the following: (a) normal saline, $(b)$ preimmune rabbit $I g G 10 \mathrm{mg} / \mathrm{ml},(c)$ rabbit antild $I g G(10 \mathrm{mg} / \mathrm{ml}$ per day), (d) TT $(10 \mu \mathrm{g} / \mathrm{ml})$, and (e) grass antigen (500 protein nitrogen units $/ \mathrm{ml}$ ). For the next $20 \mathrm{~min}$ the skin sites were inspected for the presence of a wheal and flare reaction and at the end of the $20 \mathrm{~min}$ the size of the reaction was measured. A reaction was considered positive if the size of the wheal was threefold or more the size of the wheal present at the site of injection of saline. The rabbit $\mathrm{IgG}(10 \mathrm{mg} / \mathrm{ml})$ used for elicitation of the $\mathrm{P}-\mathrm{K}$ reaction was centrifuged for $30 \mathrm{~min}$ at $15,000 \mathrm{~g}$ to remove aggregates.

\section{RESULTS}

IgE antibodies in the serum and serum fractions of the idiotype donor. IgE antibodies to TT and grass antigen were present in the serum and to a lesser extent in the IgG-enriched fraction of the idiotype donor (Table I, lines 1 and 2). Following absorption of the IgG-enriched serum fraction over insolubilized rabbit antihuman IgE, its content of IgE dropped to $0.5 \mathrm{ng} /$ $\mathrm{ml}$ and IgE antibodies to TT and grass antigen became undetectable in this fraction (Table I, line 3). No IgE or IgE anti-TT antibodies could be detected in the IgG $\mathrm{F}\left(\mathrm{ab}^{\prime}\right)_{2}$ anti-TT fraction used for immunization.

Radioimmunoassay of the antild antiserum. The capacity of rabbit antiId IgG $(10 \mathrm{mg} / \mathrm{ml})$ to precipitate ${ }^{125}$ I-labeled IgG $\mathrm{F}\left(\mathrm{ab}^{\prime}\right)_{2}$ anti-TT (idiotype) is depicted in Fig. la. At high concentrations, the antiserum bound $41 \%$ of the radiolabeled idiotype. In constrast rabbit antiId IgG failed to bind to ${ }^{125}$ I-labeled TT nonreactive IgG $\mathrm{F}\left(\mathrm{ab}^{\prime}\right)_{2}$. Preimmune rabbit IgG bound negligible amounts $(<1 \%)$ of radiolabeled idiotype (data not shown).

Inhibition of TT antigen binding to IgG by antiId antiserum. Rabbit antiId IgG inhibited by up to a maximum of $44 \%$ of the binding of TT antigen to IgG from the idiotype donor (Fig. lb). In contrast, antild IgG did not inhibit the binding of DT antigen to the same IgG. Preimmune rabbit IgG failed to inhibit TT binding to IgG (data not shown).

Elicitation of $P-K$ reactions by antiId antiserum. Antild IgG, TT, and grass antigen each elicited a positive $\mathrm{P}-\mathrm{K}$ reaction in skin sites that had been sensitized $48 \mathrm{~h}$ earlier with either serum from the idiotype donor or with Ig-enriched serum fraction, but failed to elicit a $\mathrm{P}-\mathrm{K}$ reaction in skin sites sensitized with normal saline (Table II, lines 1,2 , and 4 ). No P-K reactions could be elicited in skin sites sensitized with serum and challenged with either saline or preimmune rabbit IgG (data not shown). In no instance was there a reaction at the skin sites within the first $5 \mathrm{~min}$ of the P-K testing suggesting the absence of immediate irritant reactions.

Concentrations of rabbit antiId IgG as low as 0.05 $\mathrm{mg} / \mathrm{ml}$ could elicit a positive $\mathrm{P}-\mathrm{K}$ reaction in skin sites sensitized with serum from the idiotype donor (data not shown). However, in all subsequent experiments the concentration of rabbit antild IgG raised for the elicitation of the $\mathrm{P}-\mathrm{K}$ reaction was $10 \mathrm{mg} / \mathrm{ml}$ to ensure an excess of antild IgG.

Prior treatment of serum with heat $\left(56^{\circ} \mathrm{C}, 1 \mathrm{~h}\right)$ abolished its capacity to sensitize skin sites for a P-K reaction (Table II, line 3 ) suggesting that the sensitiz- 
TABLE I

Total IgG and IgE Content of Different Serum Fractions

\begin{tabular}{|c|c|c|c|c|c|}
\hline \multirow[b]{2}{*}{ Serum fraction ${ }^{\circ}$} & \multirow[b]{2}{*}{$\operatorname{Ig} \mathbf{G} \mathfrak{t}$} & \multirow[b]{2}{*}{$\begin{array}{l}\text { Hemagglutination } \\
\text { titer for SRBC-TT }\end{array}$} & \multirow[b]{2}{*}{$\operatorname{lgE\S "}$} & \multicolumn{2}{|c|}{$\begin{array}{l}{ }^{125} \text { I-anti-IgE" bound } \\
\text { in RAST to disks } \\
\text { coupled with: }\end{array}$} \\
\hline & & & & TT & Grass \\
\hline & $n g / m l$ & & $n g / m l$ & \multicolumn{2}{|c|}{$\%$} \\
\hline Serum & 10.8 & $1: 16,000$ & 1,920 & 9.3 & 12.8 \\
\hline IgG & 10.0 & $1: 16,000$ & 340 & 3.7 & 5.6 \\
\hline \multicolumn{6}{|l|}{ IgG absorbed against } \\
\hline antihuman IgE & 10.0 & $1: 16,000$ & 0.5 & 0 & 0.1 \\
\hline $\operatorname{IgG} F\left(a b^{\prime}\right)_{2}$ anti-TT & 1.0 & $1: 800,000$ & $<0.15$ & 0 & ND \\
\hline
\end{tabular}

- The volume of the IgG fraction was $500 \mathrm{ml}$ whereas the volume of the $\operatorname{IgG} \mathrm{F}(\mathrm{ab})_{2}$ anti-TT fraction was $5 \mathrm{ml}$.

$\downarrow$ IgG concentrations were determined by radial immunodiffusion using IgG and IgG $\mathrm{F}\left(\mathrm{ab}^{\prime}\right)_{2}$ standards as indicated.

$\$$ Ige was determined by radioimmunoassay using an ${ }^{125} \mathrm{I}$-anti-IgE (ND) rabbit antiserum (Pharmacia Fine Chemicals.) IgE (P.S.), and IgE $F\left(a^{\prime}\right)_{2}$ standards as indicated.

IgE and antigen-specific IgE were determined by paper radioimmunosorbent test and radioallergosorbent test assay on samples of serum and of IgG-enriched serum fraction and by solid-phase radioimmunoassay on samples of $\operatorname{IgG}$ absorbed against antihuman $\operatorname{IgE}$ and of $\operatorname{IgG} F\left(a b^{\prime}\right)_{2}$ anti-TT. ND, not detectable. SRBC, sheep red blood cells.

ing antibodies in the serum were of the IgE isotype. This was confirmed by demonstrating that the ability of the Ig-enriched fraction to sensitize skin sites for P-K reactions with TT, antiId IgG, and grass antigen was lost after absorption over a rabbit anti-IgE immunosorbent (Table II, line 5) but not after absorption over a rabbit antihuman IgG immunosorbent (data not shown). In contrast, the material that was eluted from

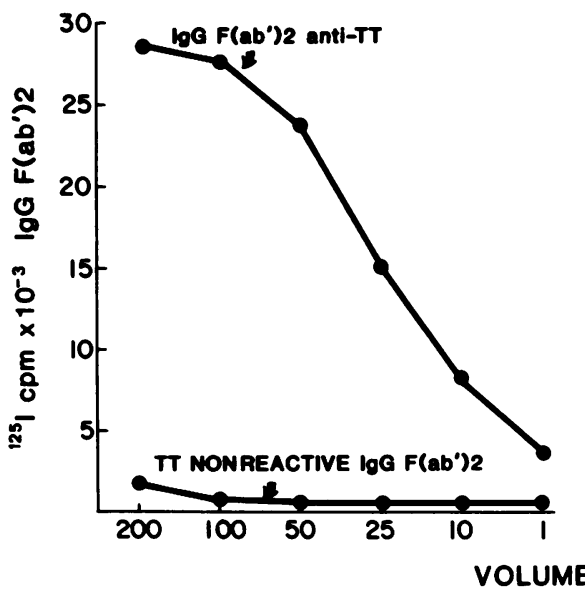

b

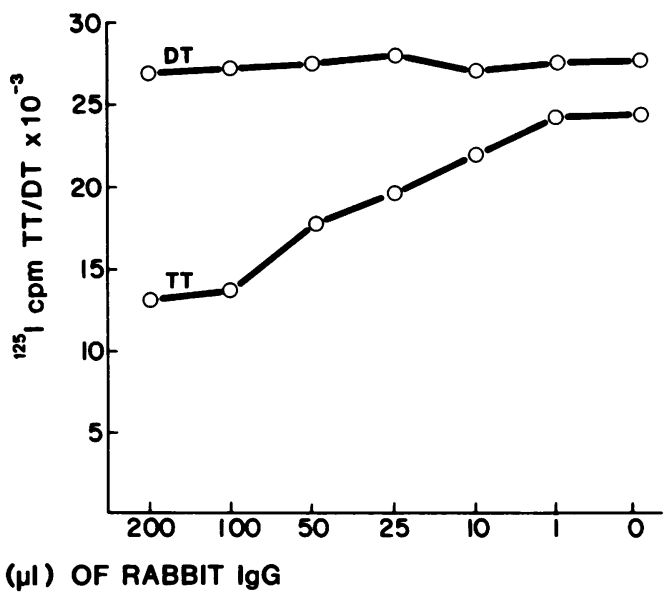

Figure 1 Characteristics of the rabbit antiId IgG. Panel A shows the capacity of the rabbit antiId IgG (10 mg IgG/ml) to bind to ${ }^{125} \mathrm{I}-\mathrm{F}\left(\mathrm{ab}^{\prime}\right)_{2} \mathrm{IgG}$ anti-TT $(26 \mathrm{ng}, 2,700 \mathrm{cpm} / \mathrm{ng})$ and to ${ }^{125}$ I-TT nonreactive $\mathrm{F}\left(\mathrm{ab}^{\prime}\right)_{2}$ IgG $(10 \mathrm{ng}, 3,800 \mathrm{cpm} / \mathrm{ng})$. Panel B shows the inhibition by rabbit antiId IgG of the binding of ${ }^{125} \mathrm{I}-\mathrm{TT}$ and of ${ }^{125} \mathrm{I}-\mathrm{DT}$ to IgG derived from the idiotype donor. In this experiment $1.5 \mu \mathrm{g}$ of $\mathrm{IgG}$ was used to bind $70 \%$ of the radioactivity present in $10 \mathrm{ng}$ of ${ }^{125} \mathrm{I}$-TT $(\sim 3,500 \mathrm{cpm} / \mathrm{ng})$ and $20 \mu \mathrm{g}$ of $\mathrm{IgG}$ were used to bind $70 \%$ of the radioactivity in $13 \mathrm{ng}$ of ${ }^{125} \mathrm{I}-\mathrm{DT}(\sim 3,000 \mathrm{cpm} / \mathrm{ng})$. All assays were performed in duplicates. Similar results were obtained in two different experiments. 
TABLE II

Elicitation of P-K Reactions by Antigen and by Antild Antibody

\begin{tabular}{|c|c|c|c|c|c|}
\hline \multirow[b]{2}{*}{ Sensitizing fraction } & \multirow[b]{2}{*}{ IgG } & \multirow[b]{2}{*}{ IgE } & \multicolumn{3}{|c|}{$\begin{array}{l}\text { Maximal dilution of sensitizing fraction } \\
\text { resulting in a positive P-K reaction } \\
\text { following challenge with: }\end{array}$} \\
\hline & & & TT & Antild IgG & Grass \\
\hline & $m g / m l$ & $n g / m l$ & & & \\
\hline Normal saline & - & - & $<1: 10$ & $<1: 10$ & $<1: 10$ \\
\hline Serum & 10.8 & 1,920 & $1: 500$ & $1: 100$ & $1: 1,000$ \\
\hline $\begin{array}{l}\text { Serum, heat-treated }\left(56^{\circ}, 1 \mathrm{~h}\right) \\
\text { Ig-rich fraction }(50 \%\end{array}$ & ND & ND & $<1: 10$ & $<1: 10$ & $<1: 10$ \\
\hline $\begin{array}{l}\text { ammonium sulfate cut) } \\
\text { Ig-rich fraction not bound to }\end{array}$ & 9.2 & 1,430 & $1: 500$ & $1: 100$ & $1: 1,000$ \\
\hline $\begin{array}{l}\text { the anti-IgE column } \\
\text { IgE-rich fraction eluted from } \\
\text { the anti-IgE column (IgE- } \\
\text { rich fraction) }\end{array}$ & $7 \times 10^{-2}$ & 1,280 & $<1: 10$ & $<1: 10$ & $<1: 10$ \\
\hline $\begin{array}{l}\text { IgE-rich fraction absorbed } \\
\text { against rabbit antihuman }\end{array}$ & & & & & \\
\hline IgG & $5 \times 10^{-4}$ & 1,140 & $1: 500$ & $1: 100$ & $1: 1,000$ \\
\hline $\begin{array}{l}\text { IgE-rich fraction absorbed } \\
\text { against rabbit antihuman } \\
\text { IgG and against } S \text {. aureus }\end{array}$ & $<3 \times 10^{-5}$ & 1,050 & $1: 500$ & $1: 100$ & $1: 1,000$ \\
\hline
\end{tabular}

All serum fractions were prepared from the serum of the donor against whose $F\left(a b^{\prime}\right)_{2}$ anti-TT the antiId was raised. Each P-K test was performed on at least two separate occasions at a 10-d interval using the same recipient with exactly the same results. All readings were done blinded. ND, not detectable.

the anti-IgE immunosorbent and that was enriched for IgE was as efficient as unfractionated serum in its ability to sensitize for P-K reactions with TT, antild IgG, and grass antigen (Table II, line 6). Because during the fractionation procedures mixed aggregates of $\operatorname{IgE}$ and IgG could have formed, the possibility was raised that the $\mathrm{P}-\mathrm{K}$ reaction was caused by the interaction of antild IgG with IgG linked to IgE rather than by the interaction of antiId IgG with IgE directly. To rule out this possibility the IgE-rich fraction was passaged over an anti-IgG immunosorbent, then absorbed with $S$. aureus to remove any residual IgG. Neither the absorption with anti-IgG nor the subsequent absorption with $S$. aureus affected the capacity of the IgE-rich fraction to sensitize skin sites for a $P-K$ reaction with antiId IgG although the amount of IgG in the doubleabsorbed sample was reduced to $<30 \mathrm{ng} / \mathrm{ml}$, which was the lower limit of the sensitivity of the radioimmunoassay used for IgG. These results strongly suggest that the P-K reaction elicited by antild IgG resulted from the direct interaction of the antild with IgE.

In all the above experiments, TT antigen seemed to be more efficient than antild IgG in eliciting a positive $P-K$ reaction in skin sites sensitized with serum and
IgE containing serum fractions (Table II). For instance TT elicited a P-K reaction in skin sites sensitized with serum diluted down to 1:500 whereas antiId IgG failed to elicit a P-K reaction in skin sites sensitized with serum diluted to lower than 1:100 (Table II, line 2).

Specificity of the IgE antibody involved in the P$K$ reaction. The antigen specificity of the IgE antibody involved in the $P-K$ reaction elicited by the antiId IgG was next examined. Absorption of the IgE-rich serum fraction against TT totally abolished its capacity to sensitize skin for a P-K reaction with antiId IgG and TT but did not affect its capacity to sensitize for a $P$ $K$ reaction with grass antigen (Table III, lines 1 and 2 ). Absorption of the IgE-rich fraction against insolubilized DT antigen did not affect its capacity to sensitize skin for a P-K reaction with antild IgG (Table II, line 3). Absorption of IgE-rich serum fractions against antild IgG resulted in a total loss of their capacity to sensitize skin for a P-K reaction with antild IgG and in a partial loss of their capacity to sensitize skin for a P-K reaction with TT, but did not affect their capacity to sensitize skin for a P-K reaction with grass antigen (Table III, line 4). In contrast, absorption of the IgE-rich serum fraction against rabbit preim- 
TABLE III

Specificity of the P-K Reactions Elicited by AntiId Antibody to Anti-TT

\begin{tabular}{|c|c|c|c|}
\hline \multirow[b]{2}{*}{ Sensitizing fraction } & \multicolumn{3}{|c|}{$\begin{array}{c}\text { Maximal dilution of sensitizing fraction resulting in a } \\
\text { positive } \mathrm{P}-\mathrm{K} \text { reaction } \\
\text { following challenge with: }\end{array}$} \\
\hline & TT & Antild IgG & Grass \\
\hline IgE-rich fraction of idiotype donor & $1: 500$ & $1: 100$ & $1: 1,000$ \\
\hline IgE-rich fraction absorbed against TT & $<1: 10$ & $<1: 10$ & $1: 1,000$ \\
\hline IgE-rich fraction absorbed against DT & $1: 500$ & $1: 100$ & $1: 1,000$ \\
\hline $\begin{array}{l}\text { IgE-rich fraction absorbed against } \\
\text { rabbit antild IgG }\end{array}$ & $1: 100$ & $<1: 10$ & $1: 1,000$ \\
\hline $\begin{array}{l}\text { IgE-rich fraction absorbed against } \\
\text { preimmune rabbit IgG }\end{array}$ & $1: 500$ & $1: 100$ & $1: 1,000$ \\
\hline $\begin{array}{l}\text { Serum from an unrelated individual } \\
\text { containing IgE antibodies to TT }\end{array}$ & $1: 1,000$ & $<1: 10$ & $<1: 10$ \\
\hline
\end{tabular}

Each P-K test was performed at least on two separate occasions at a 10-d interval using the same recipient with exactly the same results.

mune rabbit IgG did not affect its capacity to sensitize skin sites for a P-K reaction with TT, or antild IgG (Table III, line 5).

TT, but not antiId IgG, or grass antigen could elicit a $\mathrm{P}-\mathrm{K}$ reaction in skin sites sensitized with serum from an unrelated subject that contained IgE antibodies to TT $\left(11.2 \%{ }^{125} \mathrm{I}\right.$-anti-IgE binding to TT-coupled disk in RAST assay) but not to grass antigen (Table II, line 6).

\section{DISCUSSION}

The studies reported in the present communication demonstrate that human IgG and IgE antibodies to TT share idiotypic determinants because an antild serum raised against purified IgG $\mathrm{F}\left(\mathrm{ab}^{\prime}\right)_{2}$ anti-TT (idiotype) was able to elicit a positive $\mathrm{P}-\mathrm{K}$ reaction when injected into normal skin sites previously sensitized with IgE anti-TT containing serum derived from the idiotype donor.

Because it has been previously reported that human IgG can sensitize skin for a $\mathrm{P}-\mathrm{K}$ reaction (6) it was imperative to demonstrate that the positive $\mathrm{P}-\mathrm{K}$ reaction elicited by the antiId antiserum was due to the interaction of the antiserum with idiotypic determinants expressed on IgE anti-TT antibodies present in the sensitizing serum. This was indeed the case because serum lost its capacity to sensitize for a $\mathrm{P}-\mathrm{K}$ reaction following heat treatment $\left(56^{\circ} \mathrm{C}, 1 \mathrm{~h}\right)$ (Table II, line 3) and because the Ig-enriched serum fraction totally lost its capacity to sensitize for a P-K reaction following its absorption over an anti-IgE column (Table II, line 5). Furthermore, it was demonstrated that the P-K reaction resulted from interaction between antiId an- tiserum and IgE in the IgE-rich fraction rather than between antild antiserum and IgG, which could have formed mixed aggregates with $\operatorname{IgE}$ during the storage and fractionation procedures. Indeed, absorption of the IgE-rich fraction over an anti-IgG column, followed by absorption over $S$. aureus removed all detectable IgG from the IgE-rich fraction without affecting the capacity of this fraction to sensitize skin for a P-K reaction with antiId (Table I, lines 7 and 8 ).

The $\mathrm{P}-\mathrm{K}$ reactions elicited by the rabbit antild antiserum and $\operatorname{IgE}$ antibodies resulted from interaction of the rabbit antild antiserum with idiotypic determinants on IgE anti-TT antibodies rather than from interactions involving allotypic determinants on IgE. This is because antiId IgG did not elicit a P-K reaction in skin sites sensitized with IgE-enriched material that has been preabsorbed with TT (Table III, line 2). The possibility that the $\mathrm{P}-\mathrm{K}$ reactions observed with antiId IgG resulted from idiotypic interactions involving determinants specific for $\operatorname{IgE}$ anti-TT antibodies rather than determinants shared by $\operatorname{IgG}$ and $\operatorname{IgE}$ antibodies to TT was considered. However this seems extremely unlikely because the $\operatorname{IgG~} \mathrm{F}\left(\mathrm{ab}^{\prime}\right)_{2}$ anti-TT fraction used to raise the antild antiserum contained undetectable amounts $(<150 \mathrm{pg} / \mathrm{ml})$ of IgE, making it improbable for IgE anti-TT antibodies contaminating this fraction to be present in enough quantities to be immunogenic.

Although the data presented in this paper indicate that anti-TT antibodies of the IgE and IgG isotypes share idiotypic determinants, they do not rule out the presence of additional idiotypic determinants that would be specific for one or the other of the two isotypes. This is because the antild antiserum we used reacted only with a fraction of IgG anti-TT antibodies 
as illustrated by the data depicted in Figs. $1 \mathrm{a}$ and $\mathrm{lb}$ and with only a fraction of IgE anti-TT antibodies. This latter point is illustrated by the failure of the antild column to completely absorb all IgE anti-TT antibodies (Table III, line 4) and probably accounts for the greater efficiency of TT, compared with antild $\operatorname{IgG}$ as an elicitor of the P-K reaction (Tables II and III). The failure of the antiId antiserum to react with all the IgG anti-TT antibodies is not surprising because the IgG anti-TT antibodies used to raise the antiId are a mixture of heterogenous clonotypes some of which are present in quantities too low to elicit an antild response in the rabbit (7). Nevertheless, despite the heterogeneity of idiotypic determinants recognized by our antild serum, we have clearly shown previously that after appropriate absorptions our antiId antiserum recognizes anti-TT-specific idiotypic determinants that are also restricted to the idiotype donor (reference 5 and Fig. 1). The present work further illustrates that the idiotypic determinants detected on IgE anti-TT antibodies are restricted to the idiotype donor. Indeed, absorption of the IgE-rich fraction over DT antigen did not affect its interaction with antiId in a P-K reaction (Table III, line 3) and antild antibodies did not elicit a P-K reaction in skin sites sensitized with serum derived from an individual not related to the "idiotype" donor although that serum contained IgE antiTT antibodies (Table III, line 6).

Although the present data indicates that $\operatorname{IgE}$ as well as IgG antibodies bear idiotypic determinants restricted to the anti-TT antibodies of the idiotype donor it does not rule out the presence of cross-reactive idiotypic determinants shared between different individuals, nor the presence of framework idiotypic determinants shared between antibodies from the same donor directed to unrelated antigens. Indeed the way our antild antisera were absorbed i.e., against pooled IgG and against TT nonreactive IgG of the idiotype donor would preclude the detection of such shared determinants. In this context using different absorption procedures we have been able to demonstrate cross-reactive idiotypic determinants on IgG anti-TT antibodies of related family members and to obtain evidence for the presence of shared idiotypic determinants between IgG anti-TT antibodies and TT nonreactive $\mathrm{IgG} .^{2}$

The demonstration of shared idiotypic determinants on human IgG and IgE antibodies extend to man the findings of Dessein et al. in the mouse (1) and suggest that human IgE B cells can express the same set of $V$ region genes as the human IgG B cells. This notion is

\footnotetext{
${ }^{2}$ Geha, R. S. Manuscript in preparation.
}

consistent with the recent demonstration of Katz (8) that the vast majority of murine IgE-secreting clones were also secreting at least two other isotypes in addition to IgE. As demonstrated by Ishizaka $(9,10)$, Katz (11), Buckley $(12,13)$, Saxon (3), us (14), and others IgE synthesis in experimental animals and in man is regulated by isotype-specific $T$ cells, serum factors, and cell-derived factors. Not much is known, however, about the fine specificity of the regulation of the synthesis of antigen-specific antibody. Such regulation clearly occurs in the case of IgG, both, in experimental animals and in man (15). In the case of $\mathrm{IgE}$, Blaser et al. (16) have demonstrated that administration of antiId antibodies suppressed IgE synthesis in response to the benzylpenicilloyl determinant in vivo for prolonged periods of time.

In light of the above data on the role of idiotypicantiidiotypic interaction in immune regulation, our present data raise the important question of whether idiotypic-antiidiotypic interactions play a role in the regulation of human IgE synthesis. In this regard, we have previously demonstrated that such interactions can regulate human IgG anti-TT synthesis in vitro (17, 18). Furthermore, we have recently demonstrated that rabbit antild raised against antibodies to TT can specifically regulate IgE anti-TT synthesis in vitro in man and we have been able to demonstrate the appearance of autoantiidiotypic antibodies to anti-TT following booster immunization with TT antigen. ${ }^{3}$ Whether modulation of specific $\operatorname{IgE}$ antibody synthesis occurs in vivo via idiotypic-antiidiotypic interactions as the above results suggest, remains to be determined. One situation currently under study in which this modulation may take place is immunotherapy with specific antigens in subjects with allergic diseases.

\section{ACKNOWLEDGMENTS}

The author wishes to thank Miss Bettina Ault, Mr. Mark Comunale, and Miss Rita Callan for technical assistance, Dr. Fred Rosen for reviewing the manuscript and Miss Melissa Smith for secretarial assistance.

Supported by U. S. Public Health Service grant AI-05877 and by grants from the National Foundation, March of Dimes, and the Rorer Corporation.

\section{REFERENCES}

1. Dessein, A., S. Ju, M. E. Dorf, B. Benacerraf, and R. N. Germain. 1980. IgG response to synthetic polypeptide antigens. II. Idiotypic analysis of the IgE response to Lglutamic acid-L-alanine-L-tyrosine (GAT). J. Immunol. 124: $71-76$.

\footnotetext{
${ }^{3}$ Geha, R. S., and M. Comunale. Manuscript in preparation.
} 
2. Ceska, M., R. Eriksson, and J. M. Varga. 1972. Radioimmunosorbent assay of allergen. J. Allergy Clin. Immunol. 49: 1-8.

3. Saxon, A., L. Morrow, and R. H. Stevens. 1980. Subpopulations of circulating $B$ cells and regulatory $T$ cells involved in in vitro immunoglobulin $\mathrm{E}$ production in atopic patients with elevated serum immunoglobulin $\mathrm{E}$. J. Clin. Invest. 65: 1457-1468.

4. Geha, R. S. 1981. Dynamics of human circulating antigen reactive cells following secondary immunization with tetanus toxoid. Clin. Immunol. Immunopathol. 19: 196-205.

5. Geha, R. S., and R. P. Weinberg. 1978. Anti-idiotypic antisera in man. I. Production and immunochemical characterization of anti-idiotypic antisera to human antitetanus antibodies. J. Immunol. 121(4): 1518-1523.

6. Parish, W. E. 1973. Reaginic and non-reaginic antibody reactions on anaphylactic participating cells. In Mechanisms of Allergy: Reagin-Mediated Hypersensitivity. L. Goodfriend, A. H. Sehon, and R. P. Orange, editors. Marcel Dekker, Inc., New York. pp. 197-220.

7. Hopper, J. E., A. B. MacDonald, and A. Nisonoff. 1970. Quantitative investigations of idiotypic interactions. II. Nonprecipitating antibodies. J. Exp. Med. 131: 41-56.

8. Teale, J. M., F. Liu, and D. H. Katz. 1981. A clonal analysis of the IgE response and its implications with regard to isotope commitment. J. Exp. Med. 153: 783792.

9. Hirashima, M., J. Yodoi, and K. Ishizaka. 1980. Regulatory role of IgE-binding factors from rat T lymphocytes. IV. Formation of IgE-binding factors in rats treated with complete Freund's adjuvant. J. Immunol. 125: 2154-2160.
10. Yodoi, J., M. Hirashima, and K. Ishizaka. 1980. Lymphocytes bearing $F c$ receptors for IgE. V. Effect of tunicamycin on the formation of IgE-potentiating factor and IgE-suppressive factor by Con A-activated lymphocytes. J. Immunol. 126: 877-882.

11. Katz, D. H., R. F. Bargatze, C. A. Bogowitz, and L. R. Katz. 1979. Regulation of IgE antibody production by serum molecules. IV. Complete Freund's adjuvant induces both enhancing and suppressive activities detectable in the serum of low and high responder mice. $J$. Immunol. 122: 2184-2190.

12. Buckley, R. H., P. M. Fiser, and W. G. Becker. 1981. In vitro studies of IgE synthesis by human blood mononuclear cells. Fed. Proc. 40(8): 2167-2170.

13. Fiser, P. M., and R. H. Buckley. 1979. Human IgE biosynthesis in vitro: studies with atopic and normal blood mononuclear cells and subpopulations. J. Immunol. 123: 1788-1794.

14. Geha, R. S., E. Reinherz, D. Leung, K. T. McKee, S. Schlossman, and F. S. Rosen. 1981. Deficiency of suppressor $\mathrm{T}$ cells in the hyperimmunoglobulin $\mathrm{E}$ syndrome. J. Clin. Invest. 68: 783-791.

15. Geha, R. S. Current concepts in immunology. 1981. N Engl. J. Med. 305: 25-28.

16. Blaser, K., T. Nakagawa, and A. L. DeWeck. 1980. Suppression of the benzylpenicilloyl (BPO) specific IgE formation with isologous antiidiotypic antibodies in BALB/c mice. J. Immunol. 125: 24-36.

17. Geha, R. S. Idiotypic determinants on human B cells. 1979. Clin. Res. 27: 471a.

18. Geha, R. S. Idiotypic determinants on human T cells. 1980. Clin. Res. 28(2): 503a. 